\title{
A Comparative Study on Recovery Pulse Rate after 12 Minute Run and Walk Test
}

\author{
Biswabandhu Nayek ${ }^{1}$ Dr. Kallol Chatterjee ${ }^{2}$ \\ Dr. Debaprasad Sahu ${ }^{3}$ \\ 1. (Guest Lecturer, Dept Of Physical Education Sree Chaitanya College Of Commerce, W.B, India) \\ 2. (Asst. Professor, P.G.G.I.P.E, Banipur North 24 Pgs. West Bengal, India) \\ 3. (Assistant Professor \& Head, Dept. Of Physical Education, Mahishadal Girls' College, W.B)
}

\begin{abstract}
The sports are a world-wide phenomenon today. In the world history, sports was a popular organization and important as today. It has been an interesting aspect for human amusement and a cultural phenomenon at great magnitude. It has got mass participation, as it attracts people either for recreations, physical fitness or performance.The effectiveness of using the heart rate (HR) as an indicator of exercise intensity to monitor of all games and sports and any physical activity. However, recently new regulations and a trend towards a more conditional games have prompted a need to revise field study procedures and demand the increased specialization of games' concerned. Yoga has been become increasingly popular in the world as a method to reduce stress and as a means of exercise and fitness training also for recovery purpose as well. The purpose of the study was to compare the differences on recovery pulse rate among, Yoga Nidra group , Savasana group and Control group, (25 of each group). For the purpose of the study 75 male B.P.Ed students from P.G.G.I.P.E Banipur North 24 pgs, West Bengal were selected as the subjects for this study. The age of the subjects was between 22-25 years. Recovery Pulse Rate was only the variable of the study. 'ANOVA' was applied to calculate the collected data at 0.05 level of significance and to indentify the significance differences among the means critical difference was used as a Post-hoc test. The result showed that there was no significant difference between Control group and Savasana group but significance difference were observed between Control group and Yoga Nidra group, and between Savasana group and Yoga Nidra group.
\end{abstract}

Key Words: Recovery pulse rate, Yoga Nidra group, Savasana group, Control group

\section{Introduction}

The world of games and sports has crossed many milestones, as a result of different achievements in general and their application in the field of sports in particular. Scientific investigation for performance of sportsmen has been playing an increasingly important role to attain excellence of performance in different sports. Now the sportsman has been able to show outstanding performance because of involvement of new scientifically substantiated training methods and means of execution of sports exercise such as sports techniques and tactics

Performance in any game or sports not only depends on physiological, psychological, sociological andscientific training factor but also on good physique, body composition, endurance, flexibility, good reaction time, co-ordination, agility, speed, strength and good body balance.

Savasana is perhaps the most important part of yoga practice. Lying on the back, the arms and legs are spread at about 45 degrees, the eyes are closed and the breath deep, using deergha (long) pranayama. The whole body is relaxed onto the floor with an awareness of the chest and abdomen rising and falling with each breath. All parts of the body are scanned for muscular tension of any kind, which is consciously released as it is found, optionally with a small repetitive movement of the area.

Yoga Nidra means Yogic Sleep. It is a state of conscious Deep Sleep. In Meditation, you remain in the Waking state of consciousness, and gently focus the mind, while allowing thought patterns, emotions, sensations, and images to arise and go on. However, in Yoga Nidra, you leave the Waking state, go past the Dreaming state, and go to Deep Sleep, yet remain awake. While Yoga Nidra is a state that is very relaxing. : it is sleep with a trace of deep awareness. In normal sleep we lose track of our self but in yoga nidra, while consciousness of the world is dim and relaxation is deep, there remains an inward lucidity and experiences may be absorbed to be recalled later. Since yoga nidra involves an aimless and effortless relaxation

Yoga Nidra is performed in the posture of Savasana, with the eyes closed or It is a systematic method of inducing complete physical, mental and emotional relaxation. The state of relaxation is reached by turning inwards, away from outer experiences if the consciousness can be separated from external awareness and from sleep it becomes very powerful and can be applied in many ways. The characteristic feature of Yoga Nidra was the systematic rotation of consciousness in the body, which originated from the tantric practice of NYASA 
(meaning to place or to take the mind to that point) NYASA, was practiced in a sitting posture and involved the use of specific mantras which were placed, felt or experienced at different parts of the body. First, the name of the part was recited, then it was visualize or touched, and the mantra was placed there. NYASA was a means of consecrating the physical body by instilling higher awareness or divine consciousness into the various parts during tantric ritual practices. For example, the Angushtadi Shadanga-nayasa was used to place mantras in the hand as follows

"Physical Education and sports are mainly based on motor skills, the psychomotor components are of great concern to physical activities, the psychomotor is concerned with muscular activities, into those movements of the body limbs or other body parts necessary for a given action. The psychomotor ability of an individual is an increasingly complex coordination of eyes, hand and mind

"Movement represents the key concern of physical education; movement is the central focus of this field of endeavor. Physical Educator strives to help human beings to move efficiently, to increase the quality of their performance, to enhance their ability to learn, and to promote their health."

"Psychomotor concerned with voluntary human movement domain including motor skill and fitness, one of the most well known arrangement in the psychomotor domain has been presented by Barrow, all human movement has been classified into six hierarchical arrangement with six level or categories these are (i) reflex movement, (ii) basic fundamental movement, (iii) perceptual ability, (iv) Physical ability, (v) skilled movement, (vi) non discursive communication. The first two levels are genetically based in the individual the second two levels provide for the myriad of movements and behaviors of a general nature. The third dual level includes the more specialized movements for learning and performance."

Psychomotor ability which is concerned with voluntary human movement, which is observable and directly associated with muscular action or motor skills are important components which help the physically disabled. Psychomotor components are required to perform any work.

Psychomotor learning has been characterized as relating to organism and situational factors necessary for the acquisition and performance of behaviors that are generally reflected by movement. Psychomotor skills include actions such as contacting, manipulating, or moving an object and controlling the body or parts of the body. These types of motor skills require a great deal of information processing preferred to use "skill" to encompass "motor," "perceptual-motor," or any other term to cover the broadest behavioral definition of learning involving the use of movement. There is virtually no difference between "intellectual" "psychomotor" implies that the "domain" is more a convenient heuristic rather than an independent entity.

\section{Statement Of The Problem}

The purpose of the study was to compare the differences on recovery pulse rate among three group (Yoga Nidra group and Savasana group, Control group).

\section{Methodology}

For the purpose of the study 75 male Physical Education students (25 Yoga nidra 25 male Savasana, and 25 male Control group) were selected randomly from P.G.G.I.P.E Banipur north 24 porganas West Bengal.

To compare the recovery pulse rate among three groups 12 minute run and walk test administered was induced to the subjects. After 12 minute run and walk test all the subjects were divided in to three equal groups. One being control group, who performed relaxative exercises by their own for the duration of 15 minutes. The another group was given 15 minutes Savasana and the anather group was given Yoga nidra for 15 minutes. After 15 minutes again the pulse rate were counted.

\begin{tabular}{|c|c|c|c|c|}
\hline Group & Test & $\begin{array}{l}\text { Pulse rate after exercise } \\
\text { for } 15 \text { minutes (mean) }\end{array}$ & Treatment & $\begin{array}{l}\text { Recovery pulse rate } \\
\text { (mean) }\end{array}$ \\
\hline Savasana group & $\begin{array}{c}12 \text { minute run } \& \text { walk } \\
\text { test }\end{array}$ & 176.32 (Beats/min) & Savasana for 15 minutes & 115.2 (Beats/min) \\
\hline Yoganidra group & $\begin{array}{c}12 \text { minute run \& walk } \\
\text { test }\end{array}$ & 169.60 (Beats/min) & $\begin{array}{c}\text { Yoganidra for } 15 \\
\text { minutes }\end{array}$ & 99.36 (Beats/min) \\
\hline Control group & $\begin{array}{c}12 \text { minute run } \& \text { walk } \\
\text { test }\end{array}$ & 173.84 (Beats/min) & $\begin{array}{l}\text { Willful } 15 \text { minutes } \\
\text { exercise }\end{array}$ & 111.12 (Beats/min) \\
\hline
\end{tabular}

ANOVA' was applied to calculate the collected data at 0.05 level of significance and to indentify the significance differences among the means critical difference was used as a Post-hoc test

\section{Finding}

To find out whether there was any significant difference among mean values of recovery pulse rate among the three groups , one way analysis of variance technique was employed. ' $F$ ' -ratio of recovery pulse rate for different groups has been presented in Table'1' and Table '2' 
Table-1

Mean and Standard Deviation on Recovery pulse rate among three groups

\begin{tabular}{|c|c|c|}
\hline Groups & Recovery pulse rate (mean) & Recovery pulse rate (S.D) \\
\hline Savasana group & $115.2($ Beats/min) & 4.27 \\
\hline Yoganidra group & 99.36 (Beats/min) & 3.62 \\
\hline Control group & 111.12 (Beats/min) & 3.15 \\
\hline
\end{tabular}

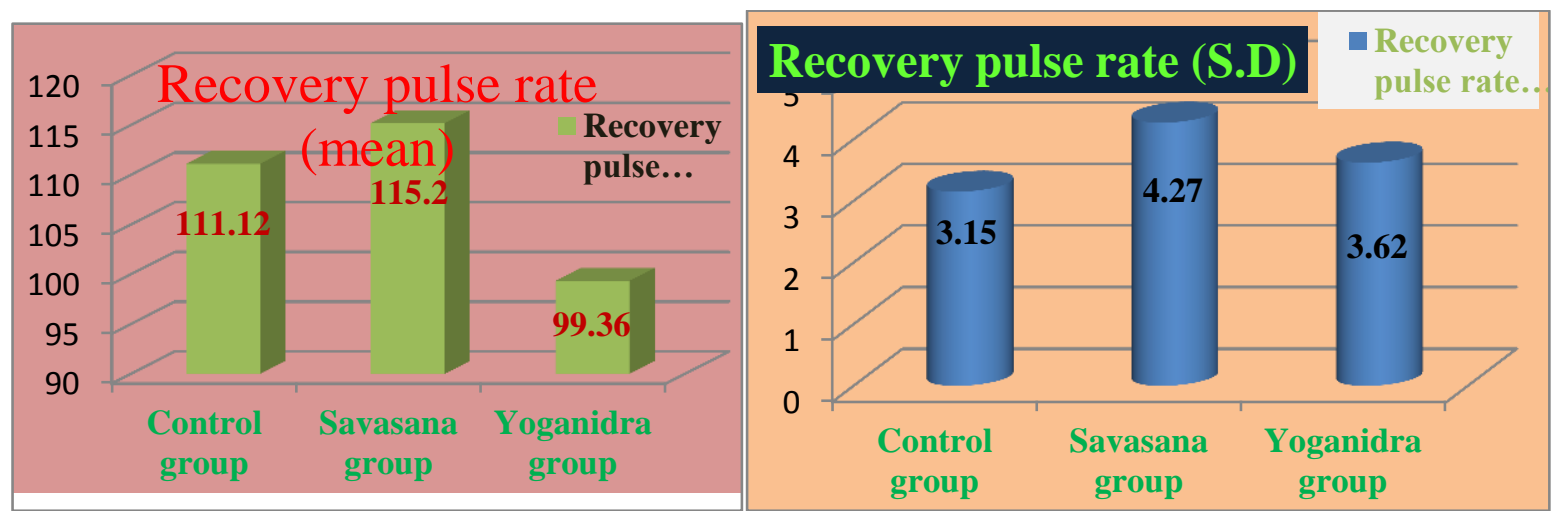

Figure- 1

Table-2

Figure 2

'F' ratio for Recovery pulse rate of different groups

\begin{tabular}{|c|c|c|c|c|c|}
\hline Variable & Source of variance & Sum of squares & $\begin{array}{c}\text { Mean square } \\
\text { variance }\end{array}$ & Degree of Freedom & 'F' ratio \\
\hline Recovery pulse rate & Between Groups & 3382.08 & 1691.04 & $(\mathrm{~K}-1)=2$ & $(\mathrm{~N}-\mathrm{K})=72$ \\
\cline { 2 - 6 } & Within Groups & 15410.40 & 214.033 & $7.90^{*}$ \\
\hline
\end{tabular}

*significant at 0.05 level of confidence: $\mathrm{F}_{0.05}(2,72)=3.11$

It was understood from table values that the calculated ' $F$ ' was statistically significant at 0.05 level of significance, confirming the significant difference among the Savasana group, Yoganidra group, and Control group, in Recovery pulse rate, in order to find out the exact location of the differences among the means critical difference was used as a Post-hoc test and presented in Table-3

Table-3

Analysis of critical difference of groups- Savasana group, Yoganidra group, Control group, in Recovery pulse rate.

\begin{tabular}{|c|c|c|c|}
\hline \multirow[t]{2}{*}{ GROUP COMPARED } & \multicolumn{3}{|c|}{ RECOVERY PULSE RATE } \\
\hline & MEAN((Beats/min) & MEAN DIFFERENCE & CRITICAL DIFFERENCE \\
\hline \multirow{2}{*}{$\begin{array}{c}\text { Control group and Savasana } \\
\text { group } \\
\end{array}$} & 111.12 & \multirow[t]{2}{*}{4.08} & \multirow[t]{2}{*}{8.19} \\
\hline & 115.20 & & \\
\hline \multirow{2}{*}{$\begin{array}{l}\text { Savasana group and } \\
\text { Yoganidra group }\end{array}$} & 115.20 & \multirow[t]{2}{*}{$15.84 *$} & \multirow[t]{2}{*}{8.19} \\
\hline & 99.36 & & \\
\hline \multirow{2}{*}{$\begin{array}{l}\text { Yoganidra group and } \\
\text { Control group }\end{array}$} & 99.36 & \multirow[t]{2}{*}{$11.76^{*}$} & \multirow[t]{2}{*}{8.19} \\
\hline & 111.12 & & \\
\hline
\end{tabular}

\section{Discussion}

From the finding of table-3 it is observed that the comparison to Control group and Savasana group in Recovery pulse rate the mean difference was 4.8 it less than critical difference so it was not significant. Because of the fact that the subjects assumed different positions for their relaxation (Half sleep, Sami sitting, mild walking and some slow and continuous stretching supplying exercise) in varied positions of lying or sitting muscles were not completely relaxed as well as the body and mind were relaxer as compare savasana and Yoga nidra group and there fore no critical differences were found. In comparison to Savasana group and Yoganidra group in Recovery pulse rate the mean difference was 15.84, it higher than critical difference so it was significant and comparison to Yoganidra group and Control group in Recovery pulse rate the mean difference was 11.76 which also higher than critical difference so it was significant. The fact may be describe due to that Savasana is perhaps the most important part of Yoga practice lying on the back, the arms and legs are spread at about degree and eyes are closed and the breath due all parts of the body are scanned for muscular tension of any kind, which is consciously relaxed that's why the recovery pulse rate reduced on the other hand. In Recovery pulse rate yoga nidra was more effective than the control groups and savasana group. Because Yoga 
Nidra play a vital role in ensuring psychological health and well being of children. Yoga Nidra helps in regaining the point of balance and harmony in every sphere of existence. Yoga Nidra is a systematic method of inducing complete physical, mental and emotional relaxation. Yoga Nidra is often referred to as psychic sleep or deep relaxation with inner awareness in this threshold state between sleep and wakefulness. In Yoga Nidra, the state of relaxation is reached by turning inwards, away from outer experiences. It not only concern about different muscles but also concern about breathing and mental relaxation. It considers the human being as a whole. It gives relaxation effect to the muscular system and nervous system and also develop strengthens muscles and Neuro- pathway. Therefore it is and recovery pulse rate reduced significantly than that of sovasana.

\section{Conclusion}

- Not significant difference between Control group and Savasana group

- Significant difference between Savasana group and Yoganidra group

- $\quad$ Significant difference between Yoganidra group and Control group

\section{Acknowledgement}

It is real pleasure that, I record my indebtedness to my teacher Dr.A.K.Bose for his counsel and guidance during the preparation of this research paper. I am also grateful to, my father mother and sister for all the suggestions offered an encouragement given to me. My thanks are due to all the students who acted as a subject for the study. With their voluntary and wholehearted support could not have been completed. Specially thanks to all the teacher of P.G.G.I.P.E. Banipur North 24 porganas West Bengal.

\section{Journal Papers:}

\section{References}

[1]. Dwivedi, S.K.(2009). The effect of Yoga nidra on Anxiety. Shodh Dhara, 12(2), 80-84

[2]. Kumar, Kamakhya (2004) Yoga nidra and its impact on student's well being; Yoga Mimamsha, Kaivalyadhama, Lonavla; Vol.36 No.1

[3]. Kumar, Kamakhya (2005) Effect of Yoga nidra on hypertension and other psychological co-relates; Yoga the Science; Yoga Publications, Hubli, Karnataka; Volume 3, Issue 7.

[4]. Nikhra.M. \& Dwivedi,S.K.(2010). A Study of the Effect of Meditation on Stress. Indian Journal of Psychology and Mental Health,4(6),78-81

[5]. Saraswati, Swami Satyananda (1 August 2003). Yoga Nidra. Yoga Publications Trust. ISBN 978-81-85787-12-1.

[6]. Saraswati, Swami Yogeshwranand (1972). Science of soul: a practical exposition of ancient method of visualisation of soul. Yoga Niketan Trust.

[7]. ANAND, B; CHHINA, G, SINGH, B (1 June 1961). "Some aspects of electroencephalographic studies in Yogis". Electroencephalography and Clinical Neurophysiology 13 (3): 452-456.doi:10.1016/0013-4694(61)90015-3.

[8]. Boyd, D. (1995). Swami: Encounters with modern mystics. Honesdale, PA: Himalayan Publishers.

[9]. Brown, K.W., Ryan, R.M., \& Creswell, J.D. (in press). Mindfulness: Theoretical foundations and evidence for its salutary effects.

[10]. Kasamatsu, Akira; Hirai, Tomio (1 December 1966). "AN ELECTROENCEPHALOGRAPHIC STUDY ON THE ZEN MEDITATION (ZAZEN)". Psychiatry and Clinical Neurosciences

[11]. Iyengar, B. K. S. (1 October 2005). Illustrated Light On Yoga. HarperCollins. ISBN 978-81-7223-606-9.

[12]. Saraswati, Swami Janakananda (1 February 1992). Yoga, Tantra and Meditation in Daily Life. Weiser Books. ISBN 978-0-87728768-1.

[13]. Saraswati, Swami Satyananda (1 August 2003). Asana Pranayama Mudra Bandha. Nesma Books India. ISBN 978-81-86336-14-4.

[14]. Saraswati, Swami Satyananda (January 2004). A Systematic Course in the Ancient Tantric Techniques of Yoga and Kriya. Nesma Books India. ISBN 978-81-85787-08-4. Retrieved 9 April 2011.

[15]. www.myyogaonline.com/poses/restorative/corpse-pose-savasana

[16]. www.yogalearningcenter.com/poses/relaxation_pose

[17]. www.yogalearningcenter.com/poses/relaxation_pose

Books:

[1]. Verma J Prakash "A TEXT BOOK ON SPORTS STATISTICS" 